University of Nebraska - Lincoln

DigitalCommons@University of Nebraska - Lincoln

Nebraska Cooperative Fish \& Wildlife Research Nebraska Cooperative Fish \& Wildlife Research Unit -- Staff Publications

2010

\title{
The effect of predation on stunted and nonstunted white perch
}

\author{
Nathan J.C. Gosch \\ Missouri Department of Conservation-Sedalia Office, Nathan.J.Gosch@usace.army.mil \\ L. L. Pierce \\ South Dakota State University \\ Kevin L. Pope \\ University of Nebraska-Lincoln, kpope2@unl.edu
}

Follow this and additional works at: https://digitalcommons.unl.edu/ncfwrustaff

Part of the Other Environmental Sciences Commons

Gosch, Nathan J.C.; Pierce, L. L.; and Pope, Kevin L., "The effect of predation on stunted and nonstunted white perch" (2010). Nebraska Cooperative Fish \& Wildlife Research Unit -- Staff Publications. 43.

https://digitalcommons.unl.edu/ncfwrustaff/43

This Article is brought to you for free and open access by the Nebraska Cooperative Fish \& Wildlife Research Unit at DigitalCommons@University of Nebraska - Lincoln. It has been accepted for inclusion in Nebraska Cooperative Fish \& Wildlife Research Unit -- Staff Publications by an authorized administrator of DigitalCommons@University of Nebraska - Lincoln. 


\section{The effect of predation on stunted and nonstunted white perch}

Gosch NJC, Pierce LL, Pope KL. The effect of predation on stunted and nonstunted white perch.

Ecology of Freshwater Fish 2010: 19: 401-407. (C) 2010 John Wiley \& Sons A/S

Abstract - Predation is widely regarded as a means to prevent or minimise the establishment of a stunted (high density of slow growing individuals) population. We investigated the effect of predation on two different white perch Morone americana populations (stunted and nonstunted) by examining the stomach contents of piscivorous fishes. White perch and gizzard shad dominated piscivore diets in Branched Oak Lake, whereas white perch dominated piscivore diets in Pawnee Lake. White perch consumed in the stunted population (Branched Oak Lake) were larger and older than white perch consumed in the nonstunted population (Pawnee Lake). Many of the consumed white perch in the stunted population were sexually mature and had the opportunity to spawn at least once. In contrast, all of the consumed white perch in the nonstunted population were sexually immature. Predation may have reinforced the stunting of white perch in Branched Oak Lake through removal of the largest, oldest individuals.

\section{N. J. C. Gosch, L. L. Pierce*, K. L. Pope}

USGS-Nebraska Cooperative Fish and Wildlife Research Unit, and School of Natural Resources, University of Nebraska-Lincoln, Lincoln, NE, USA

Key words: predation; stunting; white perch; Morone americana

Nathan J. C. Gosch, Missouri Department of Conservation - Sedalia Office, 2000 South Limit Avenue, Sedalia, M0 65301, USA; e-mail: nate.gosch@mdc.mo.gov

*Present address: Northern Plains Biostress Laboratory, Department of Wildlife and Fisheries Sciences, Box 2140B, South Dakota State University, Brookings, SD, USA.

Accepted for publication March 3, 2010

\section{Introduction}

Balance of fish populations in aquatic communities has long been recognised as an important concept in fishery management beginning with quantitative descriptions of balanced and unbalanced communities by Swingle (1950). Characteristics used to describe a balanced fish community include: consistent recruitment of predators and prey, diverse size distributions of predators and prey, fast growth of predators and prey, and consistent production of harvestable-sized fish in relation to the fertility of the water body (Flickinger et al. 1999). Unbalanced communities rarely produce fish that anglers desire to harvest (Swingle 1950) and a stunted population is an obvious example of an unbalanced community. Stunting is a common occurrence in freshwater fisheries that is intuitively easy to comprehend, though very difficult to quantify. As such, many definitions of stunting exist, including: a drastically reduced growth rate (Heath \& Roff 1987), a drastically reduced growth rate relative to the potential of the species (Burrough \&
Kennedy 1979), a decrease in juvenile growth followed by an almost complete stoppage of growth during adult life stages (Diana 1987), and a reduction in maximum size in relation to the ecological potential for an entire population of a species (Ylikarjula et al. 1999). This population-wide reduction in body size is a result of ecological conditions, not genetics (Heath \& Roff 1987), and it is commonly observed in Centrarchidae (Roff 1992; Aday et al. 2002), Salmonidae (L'Abèe-Lund et al. 1990; Roff 1992), and Percidae (Alm 1946; Heath \& Roff 1996; Jansen 1996; Heibo et al. 2005). Typically, this reduction in body size is accompanied by an earlier age at maturity (Burrough \& Kennedy 1979; L'Abee-Lund et al. 1990; Jansen 1996) resulting in a high-density population of slow growing individuals. Clearly, there is great need for a quantifiable definition of stunting within our profession.

Regardless of the definition, a stunted fish population is often problematic for fishery managers (Hayes et al. 1999). Despite several potential tools to alleviate stunting, such as mechanical and chemical removal, 


\section{Gosch et al.}

water-level manipulation, and stocking of predators (Noble 1980; Wydoski \& Wiley 1999), imbalance in these fish communities is difficult to correct. The role of predation, in conjunction with reproductive output of prey, has long been considered important for establishing and maintaining balance in aquatic communities (Swingle 1950; Anderson 1973). The current paradigm, first proposed by Swingle \& Smith (1942), suggests that predation is a means of preventing or minimising stunted fish populations. Fishery managers often attempt to manage unbalanced communities by stocking predators (Flinkinger et al. 1999) or increasing human harvest with intensive fishing (Swingle \& Smith 1942; Amundsen et al. 1993) because a lack of predation pressure is one factor that could cause or promote stunting of a species within a water body (Roff 1992; Ylikarjula et al. 1999). Furthermore, many studies suggest that predators could be important for improving growth and size structure of prey fishes (e.g., Rask 1983; Otis et al. 1998; Paukert et al. 2002; Tomcko \& Pierce 2005). However, exceptions to the current paradigm may exist in which predation pressure causes or reinforces stunting of a prey population. Thus, we investigated the effect of predation on two markedly different white perch Morone americana populations (i.e., stunted and nonstunted) in Branched Oak and Pawnee reservoirs, Nebraska.

\section{Study fish}

White perch tend to overpopulate and stunt in freshwater systems (Scott \& Crossman 1973). White perch are highly fecund (Mansueti 1961), have an ability to reproduce during their first year of life, and can withstand a wide range of environmental conditions allowing for potential domination of fish communities (Ballinger \& Peters 1978; Hodkin 2001). White perch may negatively affect other fishes through competition for food (Mansueti 1961; Schaeffer \& Margraf 1987; Hodkin 2001) and egg predation (Mansueti 1961; Ballinger \& Peters 1978; Schaeffer \& Margraf 1987; Hodkin 2001). In the Midwest, the white perch is an invasive species and has demonstrated a propensity to stunt in Nebraska reservoirs (Hergenrader \& Bliss 1971; Hergenrader 1980; Hodkin 2001; Chizinski 2007).

The white perch populations in Branched Oak and Pawnee reservoirs, Nebraska, are markedly different. Chizinski (2007) investigated differences in lifehistory traits between stunted white perch in Branched Oak Lake and nonstunted white perch in Pawnee Lake. Males and females were significantly smaller (standard length and somatic dry mass) in the stunted population than the nonstunted population; additionally, maximum size was smaller in the stunted population. White perch in the stunted population lived significantly longer achieving a maximum age of 10 years, whereas 5 years was the maximum age for white perch in the nonstunted population. White perch in the stunted population experienced slower growth and an annual survival rate almost twice that of white perch in the nonstunted population. Furthermore, males and females reached sexual maturity at ages 1 and 2, respectively, in the stunted population and ages 2 and 4, respectively, in the nonstunted population.

\section{Study area}

Branched Oak Lake, located in Lancaster County, Nebraska, is a 728-ha, hypereutrophic flood-control reservoir. At the time of study, Branched Oak Lake had restrictive harvest regulations (i.e., catch-andrelease fishing for hybrid striped bass Morone saxatilis $\times$ Morone chrysops and flathead catfish Pylodictis olivaris, a daily bag limit of 1 walleye Sander vitreus longer than $56 \mathrm{~cm}$, and a $25-\mathrm{cm}$ minimum length limit for white crappie Pomoxis annularis and black crappie P. nigromaculatus). Pawnee Lake is a 299-ha, hypereutrophic flood-control reservoir and is located $14 \mathrm{~km}$ south of Branched Oak Lake in Lancaster County, Nebraska. At the time of study, Pawnee Lake had less restrictive harvest regulations (i.e., daily bag limit of 10 panfish) compared to Branched Oak Lake.

\section{Materials and methods}

Diets of piscivorous fishes (largemouth bass, white crappie, black crappie, channel catfish Ictalurus punctatus, flathead catfish, white bass M. chrysops, hybrid striped bass, sauger $S$. canadensis, and walleye) were investigated during the ice-free period (approximately March through November) of 2006 and 2007 in Branched Oak and Pawnee reservoirs. Each reservoir was sampled twice weekly from $1 \mathrm{~h}$ before to $2 \mathrm{~h}$ after sunrise and from sunset to $3 \mathrm{~h}$ after sunset because catchability of fishes is maximised during crepuscular periods (Witt \& Campbell 1959). Also, some fishes feed more actively during the day, whereas other fishes feed more actively during the night.

Piscivorous fishes were captured with a boatmounted electrofisher (pulsed DC) and measured for total length (mm). Stomach contents of captured fishes were removed using pulsed gastric lavage (Light et al. 1983; Kamler \& Pope 2001) and preserved in a 10\% buffered-formalin solution. After the stomach was flushed with water, an appropriately sized clear plastic tube was inserted into the digestive tract and used as a gastroscope to ensure that all stomach contents were removed. Fish were released unharmed after stomach contents were removed. In the laboratory, all stomach contents were identified to species for fishes and to 
order for invertebrates using dichotomous keys provided by Scott \& Crossman (1973) and Thorp \& Covich (1991). Prey fishes removed from stomachs were measured for standard length $(\mathrm{mm})$ when possible. We used frequency of occurrence and percentage of composition by volume to quantitatively describe diets of piscivorous fishes.

A Kolmogorov-Smirnov test was used to determine if differences existed between length-frequency distributions of white perch sampled by Nebraska Game and Parks Commission (NGPC) fisheries biologists in Branched and Pawnee reservoirs; NGPC sampled white perch during mid-October of 2006 and 2007 with trap nets (16-mm bar mesh) and gill nets (1.8-m tall and 7.6-m wide panels of 19-, 25-, 32-, 38-, 51-, and 76-mm bar mesh). A Kolmogorov-Smirnov test was also used to determine if differences existed between length-frequency distributions of white perch consumed by piscivores from Branched Oak and Pawnee reservoirs. We visually compared lengthfrequency distributions of white perch consumed by piscivores during autumn (September-November) to length-frequency distributions of white perch sampled by NGPC. For comparison purposes, we converted standard lengths of white perch consumed by piscivores to total length using a conversion factor (total length $=$ standard length[1.24]; Carlander 1997) because NGPC measured total length during standardised fish sampling. Chizinski et al. (2010b) determined mean length-at-age for white perch collected from March until September 2006 in Branched Oak and Pawnee reservoirs; we used this age information to assign ages to white perch. We also used catch-per-unit-effort (CPUE) data from the 2006 NGPC standardised trap net (number per trap net night for white crappie and black crappie) and gill net (number per gill net night for channel catfish, white bass, hybrid striped bass, sauger, and walleye) sampling to provide a measure of relative abundance for piscivorous fishes in each reservoir. Trap nets and gill nets are not appropriate gears for indexing relative abundance for largemouth bass and flathead catfish, thus CPUE is not reported for these two species.

\section{Results}

In Branched Oak Lake, we captured 1470 piscivores with 368 of these piscivores containing white perch. Mean total length of piscivores captured in Branched Oak Lake was $485.6 \pm 4.2 \mathrm{~mm}$. Flathead catfish, hybrid striped bass, and walleye were the largest and most abundant piscivores captured by electrofishing; however, white crappie and channel catfish were the most abundant piscivores captured by trap nets and gill nets, respectively (Table 1). Piscivores consumed numerous species in Branched Oak Lake: brook
Table 1. Mean \pm SE total length $(\mathrm{mm})$, size range (total length $[\mathrm{mm}]$ of the smallest and largest individuals captured), and sample size $(n)$ for each species of piscivore captured with electrofishing for assessment of stomach contents during 2006 and 2007 in Branched Oak and Pawnee reservoirs, Nebraska. Catch-per-unit-effort (CPUE) \pm SE from Nebraska Game and Parks Commission standardised sampling during 2006 is also presented to provide an index of relative abundance of each piscivore within each reservoir. Trap nets and gill nets are not appropriate gears for indexing relative abundance for largemouth bass and flathead catfish, thus CPUE is not reported for these two species.

\begin{tabular}{clllrl}
\hline & Piscivore & Length $(\mathrm{mm})$ & $\begin{array}{l}\text { Range } \\
(\mathrm{mm})\end{array}$ & $n$ & CPUE \\
\hline $\begin{array}{c}\text { Branched } \\
\text { Oak }\end{array}$ & $\begin{array}{l}\text { Largemouth } \\
\text { bass }\end{array}$ & $369.4 \pm 12.1$ & $222-535$ & 57 & $\mathrm{~N} / \mathrm{A}$ \\
& & & & \\
& White crappie & $280.4 \pm 1.6$ & $199-379$ & 271 & $5.1 \pm 1.9$ \\
& Black crappie & $242.4 \pm 7.7$ & $202-383$ & 27 & $4.1 \pm 1.3$ \\
& Channel catfish & $448.2 \pm 13.4$ & $315-704$ & 53 & $9.5 \pm 1.4$ \\
& Flathead catfish & $640.4 \pm 8.0$ & $267-1130$ & 326 & $\mathrm{~N} / \mathrm{A}$ \\
& Hybrid striped & $515.7 \pm 5.7$ & $270-685$ & 328 & $0.8 \pm 0.5$ \\
& bass & & & & \\
& Walleye & $511.2 \pm 5.0$ & $197-706$ & 408 & $1.3 \pm 0.5$ \\
Pawnee & Largemouth & $368.7 \pm 6.5$ & $175-534$ & 110 & $\mathrm{~N} / \mathrm{A}$ \\
& bass & & & & \\
& White crappie & $254.6 \pm 6.0$ & $207-309$ & 18 & $6.6 \pm 2.4$ \\
& Black crappie & $248.7 \pm 22.4$ & $221-293$ & 3 & $3.1 \pm 0.8$ \\
& Channel catfish & $498.9 \pm 7.3$ & $339-663$ & 83 & $7.3 \pm 1.0$ \\
& Flathead catfish & $663.7 \pm 20.2$ & $374-1120$ & 82 & N/A \\
& White bass & $304.6 \pm 2.5$ & $220-374$ & 162 & $2.0 \pm 0.9$ \\
& Sauger & $508.2 \pm 2.4$ & $448-560$ & 117 & $1.3 \pm 0.5$ \\
& Walleye & $395.7 \pm 5.1$ & $199-627$ & 294 & $7.5 \pm 1.4$ \\
\hline
\end{tabular}

silverside Labidesthes sicculus, green sunfish Lepomis cyanellus, bluegill, largemouth bass, crappie spp., gizzard shad Dorosoma cepedianum, common carp Cyprinus carpio, white perch, and walleye; however, white perch and gizzard shad were the most frequent prey fishes removed from piscivore stomachs, and occurrence of other prey fishes was rare (Table 2).

Table 2. Frequency of occurrence $(\% 0)$ and percentage of composition by volume $(\% \mathrm{~V})$ for each prey fish species removed from piscivore stomachs during 2006 and 2007 in Branched Oak and Pawnee reservoirs, Nebraska.

\begin{tabular}{llrr}
\hline & Prey fish & $\% 0$ & $\% \mathrm{~V}$ \\
\hline Branched Oak & Brook silverside & $<1.0$ & $<1.0$ \\
& Green sunfish & $<1.0$ & $<1.0$ \\
Bluegill & $<1.0$ & $<1.0$ \\
& Largemouth bass & $<1.0$ & $<1.0$ \\
Crappie species & $<1.0$ & $<1.0$ \\
Gizzard shad & 47.6 & 49.2 \\
& Common carp & $<1.0$ & $<1.0$ \\
White perch & 50.1 & 43.5 \\
& Walleye & $<1.0$ & $<1.0$ \\
& Unidentifiable fish & 14.8 & 6.7 \\
& Bluegill & $<1.0$ & 6.1 \\
Lawnee & $<1.0$ & $<1.0$ \\
& Crapemouth bass & $<1.0$ & 1.5 \\
& Common carp & $<1.0$ & $<1.0$ \\
& Fathead minnow & $<1.0$ & $<1.0$ \\
White perch & 77.2 & 82.3 \\
& Walleye & $<1.0$ & 2.1 \\
& Unidentifiable fish & 21.8 & 7.1 \\
\hline
\end{tabular}




\section{Gosch et al.}

Similarly, white perch and gizzard shad dominated the volume of prey fishes consumed in Branched Oak Lake (Table 2). The majority of white perch $(77.9 \%$ of the volume of white perch consumed) were consumed during spring and summer. In contrast, the majority of gizzard shad $(75.5 \%$ of the volume of gizzard shad consumed) were consumed during autumn when young-of-year gizzard shad became vulnerable to predators. Most of white perch removed from piscivore stomachs were highly digested and could not be measured; we measured standard length of 102 white perch removed from piscivore stomachs in Branched Oak Lake.

In Pawnee Lake, we captured 869 piscivores with 254 of these piscivores containing white perch. Mean total length of piscivores captured in Pawnee Lake was $422.2 \pm 4.5 \mathrm{~mm}$. Flathead catfish and sauger were the largest piscivores sampled by electrofishing, whereas walleye and white bass were the most abundant (Table 1). White crappie was the most abundant piscivore captured by trap nets, and walleye and channel catfish were the most abundant piscivores captured by gill nets (Table 1). Piscivores consumed numerous species in Pawnee Lake: bluegill, largemouth bass, crappie spp., common carp, fathead minnow Pimephales promelas, white perch, and walleye; however, white perch was the most frequent prey fish removed from piscivore stomachs, and occurrence of other prey fishes was rare (Table 2). White perch dominated the volume of prey fishes consumed in Pawnee Lake (Table 2). Similar to Branched Oak Lake, we measured standard length of 76 white perch removed from piscivore stomachs in Pawnee Lake.

Length-frequency distributions of white perch captured by NGPC were different between reservoirs $(\mathrm{KSa}=28.2, P<0.0001)$; larger white perch were sampled in Pawnee Lake compared to Branched Oak Lake (Fig. 1). Length frequency distributions of white perch consumed by piscivores were also different $(\mathrm{KSa}=1.9, P=0.001)$ between reservoirs (Fig. 1); the size range of white perch consumed was identical between reservoirs, though relative frequency of larger white perch consumed was greater in Branched Oak Lake than Pawnee Lake. There were also differences in the ages (as determined by Chizinski et al. (2010b)) of white perch consumed by piscivores between reservoirs. In Branched Oak Lake, $42 \%$ of consumed white perch were age 1 or older, where as only $1 \%$ of consumed white perch were age 1 or older in Pawnee Lake (Fig. 1). When considering the gear bias of trap nets and gill nets (white perch $<100 \mathrm{~mm}$ were not effectively sampled by NGPC gears), piscivorous fishes in Branched Oak Lake consumed nearly the entire size range of white perch captured from trap nets and gill nets (Fig. 1). Piscivorous fishes in Pawnee

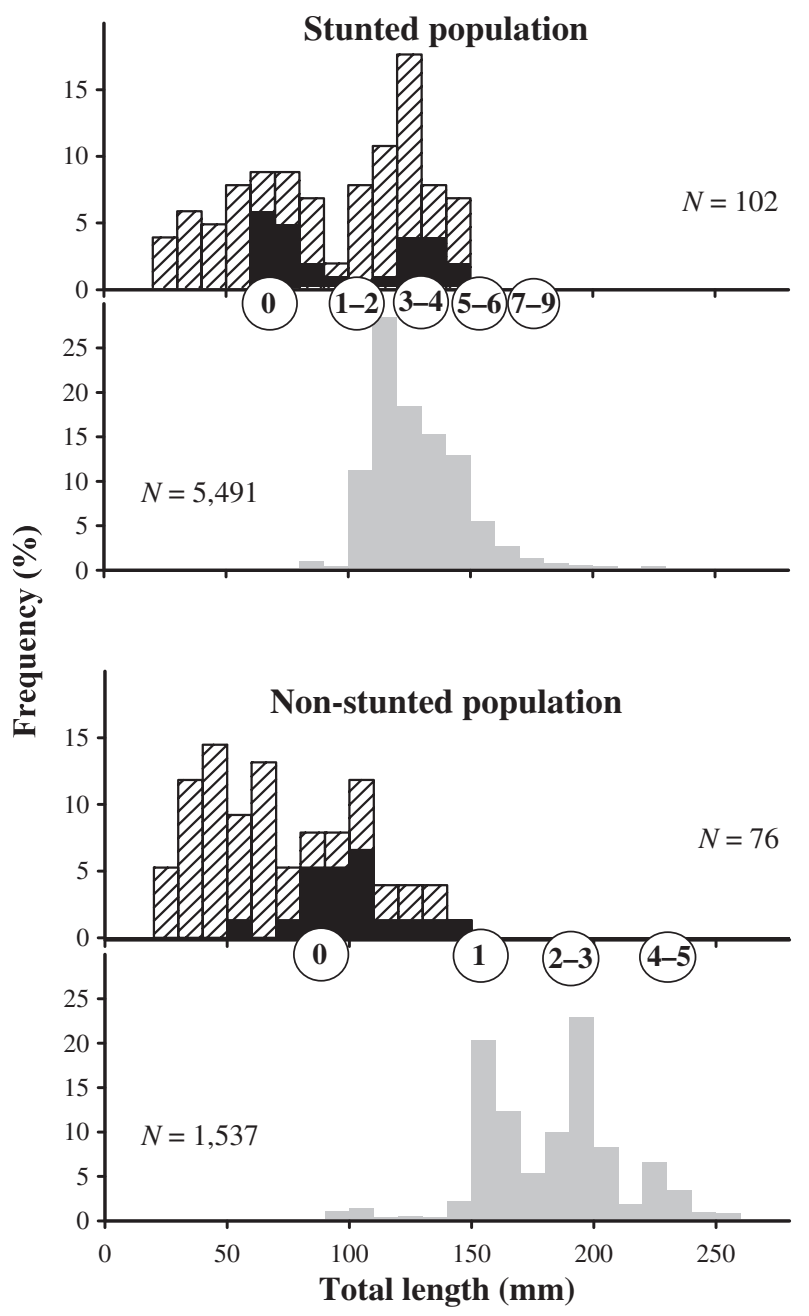

Fig. 1. Length-frequency distributions of white perch consumed by piscivores during spring-summer (March-August; cross-hatch fill) and autumn (September-November; black fill), and white perch captured by the Nebraska Game and Park Commission during autumn (mid-October; grey fill) of 2006 and 2007 in a reservoir containing a stunted white perch population (Branched Oak Lake; top two panels) and in a reservoir containing a nonstunted white perch population (Pawnee Lake; bottom two panels). Age estimates for white perch are indicated by numbers enclosed in circles that are centred on their respective length groups for each reservoir.

Lake consumed much smaller white perch compared to white perch that were captured from trap nets and gill nets (Fig. 1).

\section{Discussion}

When comparing sizes of white perch consumed from the stunted population (Branched Oak Lake) with sizes of white perch consumed from the nonstunted population (Pawnee Lake), we found that similar-sized white perch were consumed from the stunted and nonstunted population; all white perch consumed in both populations were $20-150 \mathrm{~mm}$ in total length. We 
expected larger white perch would be consumed in Pawnee Lake where larger white perch were present. However, piscivore size was greater in Branched Oak Lake compared to Pawnee Lake and larger piscivores should be able to consume larger prey items. White perch grow faster in Pawnee Lake (Chizinski 2007); perhaps white perch quickly reach a size refuge from most piscivores in Pawnee Lake. In Branched Oak Lake, piscivores consumed nearly the entire size range of white perch available. In contrast, piscivores in Pawnee Lake consumed only the smallest individuals from the size range of white perch available. Many white perch in the 150 - to $250-\mathrm{mm}$ size range were collected during autumn standardised fish sampling by NGPC; however, no white perch in this size range was removed from the stomachs of piscivores.

Piscivores in Pawnee Lake were not only consuming smaller white perch, but younger white perch as well. Piscivores almost exclusively consumed age- 0 white perch in Pawnee Lake, whereas piscivores in Branched Oak Lake consumed a wide range of ages $(0-6)$. Given that white perch mature at age 1-2 in Branched Oak Lake, white perch in this stunted population potentially spawn several times before being consumed. Our traditional view of fish population dynamics suggests that exploitation of mature white perch via predation would lead to greater reproductive output and increased recruitment, which would exacerbate the stunted status of white perch in Branched Oak Lake. Further, removal of larger, older white perch (via predation) from a population without sufficient predation on smaller, younger white perch may promote stunting. Modelling simulations indicated that increasing and maintaining predation pressure on age- 0 and age- 1 white perch consistently resulted in the greatest change in white perch population dynamics in Branched Oak Lake (Chizinski et al. 2010a). Perhaps white perch would be better controlled by a fish community similar to Pawnee Lake, which is comprised of smaller-bodied piscivores, instead of the current fish community comprised mainly of larger-bodied piscivores. In contrast, white perch mature at age 2-4 in the Pawnee Lake and evidently, white perch that survive to maturity in this population are no longer vulnerable to predation by other fishes.

The presence of gizzard shad is another factor that could be contributing to the stunting of white perch in Branched Oak Lake. First, the annual production of age-0 gizzard shad provides piscivores with an abundant, alternative prey base that likely decreases predation pressure on white perch, particularly during autumn. Gizzard shad are soft-rayed and have a greater caloric density than white perch (Miranda \& Muncy 1989) potentially making gizzard shad a more attractive prey item than white perch, at least part of the year. Second, gizzard shad can substantially reduce plankton communities and decrease growth of other fishes (Garvey \& Stein 1998). Cladocerans and dipterans were the most important prey items for white perch during 2006 and 2007 in Branched Oak Lake during spring, summer, and autumn (Gosch et al. 2010). Gizzard shad may be competing with white perch for food, limiting white perch growth and thus, providing another mechanism, in conjunction with predation, promoting a stunted population of white perch.

The current paradigm suggests that a reduction of population density is important to prevent, minimise or alleviate stunting of a fish population (Alm 1946; Donald \& Alger 1989; Amundsen et al. 1993; Klemetsen et al. 2002; Amundsen et al. 2007). Naturally, predation is a primary mechanism fishery managers use to reduce population density. In theory, increased predation should reduce population density and increase food availability to the remaining individuals allowing for increased growth rates. However, piscivores must remove the appropriate-sized (-aged) individuals for this theory to prove true. When piscivores target the larger, older individuals in a population, stunting will not necessarily be alleviated. For example, implementing a minimum length limit regulation on a high-density largemouth bass population promotes predation (by anglers) on the few individuals growing past the minimum length creating an excess of largemouth bass smaller than the minimum length. The largemouth bass population remains at high density and, if it is not stunted already, likely transitions to the stunted state. Certainly, situations exist where predation can alleviate stunting of a fish population and help restore balance in an aquatic community; however, this may not always be the case. We demonstrated herein that situations may exist where predation reinforces stunting in aquatic communities. Additional research is needed to further explore situations where the removal of the appropriate-sized (-aged) individuals may be important to alleviate stunting of a population.

\section{Acknowledgements}

We thank Jeff Stittle, John Walrath, Dustin Martin, Christopher Lewis, and Tony Barada for field and laboratory assistance and the Nebraska Game and Parks Commission for providing white perch catch data. C. Schoenebeck, M. Pegg, and R. Holland provided valuable comments on an earlier draft of this manuscript. The Nebraska Cooperative Fish and Wildlife Research Unit are jointly supported by a cooperative agreement among the U.S. Geological Survey, the Nebraska Game and Parks Commission, the University of Nebraska, the U.S. Fish and Wildlife Service, and the Wildlife Management Institute. Reference to trade names is for descriptive purposes only and does not imply endorsement by the authors or the U.S. Government. 


\section{Gosch et al.}

\section{References}

Aday, D.D., Kush, C.M., Wahl, D.H. \& Philipp, D.P. 2002. The influence of stunted body size on the reproductive ecology of bluegill Lepomis macrochirus. Ecology of Freshwater Fish 11: 190-195.

Alm, G. 1946. Reasons for the occurrence of stunted fish populations with special reference to perch. Drottningholm: Report from the Institute of Freshwater Research 25: 1-146.

Amundsen, P.A, Klemetsen, A. \& Grotnes, P.E. 1993. Rehabilitation of a stunted population of Arctic char by intensive fishing. North American Journal of Fisheries Management 13: 483-491.

Amundsen, P.A., Knudsen, R. \& Klemetsen, A. 2007. Intraspecific competition and density dependence of food consumption and growth in Arctic charr. Journal of Animal Ecology 76: 149-158.

Anderson, R.O. 1973. Application of theory and research to management of warmwater fish populations. Transactions of the American Fisheries Society 102: 164-171.

Ballinger, R.E. \& Peters, E.J. 1978. Impact of an introduced fish species (Morone Americana) on the fisheries resource of Nebraska. University of Nebraska-Lincoln: Partial Technical Completion Report and Annual Progress Report, 37 pp.

Burrough, R.J. \& Kennedy, C.R. 1979. The occurrence and natural alleviation of stunting in a population of roach, Rutilus rutilus (L.). Journal of Fish Biology 15: 93-109.

Carlander, K.D. 1997. Handbook of freshwater fish biology, volume 3. Ames: Iowa State University Press, 397 pp.

Chizinski, C.J. 2007. Variation in life-history traits and morphology of stunted and non-stunted fish. Ph.D. thesis. Lubbock, TX: Texas Tech University, $171 \mathrm{pp}$.

Chizinski, C.J., Pope, K.L. \& Wilde, G.R. 2010a. A modeling approach to evaluate potential management actions designed to increase growth of white perch in a high-density population. Fisheries Management and Ecology, published online 13 January 2010. http://www3.interscience.wiley.com/journal/ 123239115/abstract.

Chizinski, C.J., Pope, K.L., Wilde, G.R. \& Strauss, R.E. 2010 b. Implications of stunting on morphology of freshwater fishes. Journal of Fish Biology 76: 564-579.

Diana, J.S. 1987. Simulation of mechanisms causing stunting in northern pike populations. Transactions of the American Fisheries Society 116: 612-617.

Donald, D.B. \& Alger, D.J. 1989. Evaluation of exploitation as a means of improving growth in a stunted population of brook trout. North American Journal of Fisheries Management 9: 177-183.

Flickinger, S.A., Bulow, F.J. \& Willis, D.W. 1999. Small impoundments. In: Kohler, C.C. \& Hubert, W.A., eds. Inland fisheries management in North America, 2nd edn. Bethesda, MD: American Fisheries Society, pp. 561-587.

Garvey, J.E. \& Stein, R.A. 1998. Competition between larval fishes in reservoirs: the role of relative timing of appearance. Transactions of the American Fisheries Society 127: 10211039.

Gosch, N.J.C., Stittle, J.R. \& Pope, K.L. 2010. Food habits of stunted and non-stunted white perch (Morone americana). Journal of Freshwater Ecology 25: 31-39.
Hayes, D.B., Taylor, W.M. \& Soranno, P.A. 1999. Natural lakes and large impoundments. In: Kohler, C.C. \& Hubert, W.A., eds. Inland fisheries management in North America, 2nd edn. Bethesda, MD: American Fisheries Society, pp. 589-621.

Heath, D.D. \& Roff, D.A. 1987. Test of genetic differentiation in growth of stunted and nonstunted populations of yellow perch and pumpkinseed. Transactions of the American Fisheries Society 116: 98-102.

Heath, D.D. \& Roff, D.A. 1996. The role of trophic bottlenecks in stunting: a field test of an allocation model of growth and reproduction of yellow perch, Perca flavescens. Environmental Biology of Fishes 45: 53-63.

Heibo, E., Magnhagen, C. \& Vollestad, L.A. 2005. Latitudinal variation in life-history traits in Eurasian perch. Ecology 86: 3377-3386.

Hergenrader, G.L. 1980. Current distribution and potential for dispersal of white perch (Morone americana) in Nebraska and adjacent waters. American Midland Naturalist 103: 404-406.

Hergenrader, G.L. \& Bliss, Q.P. 1971. The white perch in Nebraska. Transactions of the American Fisheries Society 100: 734-738.

Hodkin, C.E. 2001. Population characteristics and food habits of white perch (Morone americana) in Branched Oak Lake, Nebraska. M.S. thesis. Lincoln, NE: University of Nebraska, pp. 83.

Jansen, W.A. 1996. Plasticity in maturity and fecundity of yellow perch, Perca flavescens (Mitchill): comparisons of stunted and normal-growing populations. Annales Zoologici Fennici 33: 403-415.

Kamler, J.F. \& Pope, K.L. 2001. Nonlethal methods of examining fish stomach contents. Reviews in Fisheries Science 9: 1-11.

Klemetsen, A., Amundsen, P.A., Grotnes, P.E., Knudsen, R., Kristoffersen, R. \& Martin, A. 2002. Takvatn through 20 years: long-term effects of an experimental mass removal of arctic charr, Salvelinus Alpinus, from a subarctic lake. Environmental Biology of Fishes 64: 39-47.

L'Abee-Lund, J.H., Jensen, A.J. \& Johnsen, B.O. 1990. Interpopulation variation in male parr maturation of anadromous brown trout Salmo trutta in Norway. Canadian Journal of Zoology 68: 1983-1987.

Light, R.W., Alder, P.H. \& Arnold, D.E. 1983. Evaluation of gastric lavage for stomach analysis. North American Journal of Fisheries Management 3: 81-85.

Mansueti, R.J. 1961. Movements, reproduction, and mortality of the white perch, Roccus americanus, in the Patuxent estuary, Maryland. Chesapeake Science 2: 142-205.

Miranda, L.E. \& Muncy, R.J. 1989. Bioenergetic values of shads and sunfishes as prey for largemouth bass. Proceedings of the Annual Conference of the Southeastern Association of Fish and Wildlife Agencies 43: 153-163.

Noble, R.L. 1980. Management of lakes, reservoirs, and ponds. In: Lackey, R.T. \& Nielsen, L.A., eds. Fisheries management. New York: Wiley, pp. 265-296.

Otis, K.J., Piette, R.R., Keppler, J.E. \& Rasmussen, P.W. 1998. A largemouth bass closed fishery to control an overabundant bluegill population in a Wisconsin lake. Journal of Freshwater Ecology 13: 391-403.

Paukert, C.P., Willis, D.W. \& Klammer, J.A. 2002. Effects of predation and environment on quality of yellow perch and 
bluegill populations in Nebraska sandhill lakes. North American Journal of Fisheries Management 22: 86-95.

Rask, M. 1983. Differences in growth of perch (Perca fluviatilis

L.) in two small forest lakes. Hydrobiologia 101: 139-144.

Roff, D.A. 1992. The evolution of life histories - theory and analysis. New York: Chapman \& Hall, 535 pp.

Schaeffer, J.S. \& Margraf, F.J. 1987. Predation on fish eggs by white perch, Morone americana, in western Lake Erie. Environmental Biology of Fishes 18: 77-80.

Scott, W.B. \& Crossman, E.J. 1973. Freshwater fishes of Canada. Ottawa: Fisheries Research Board of Canada, Bulletin 184, 966 pp.

Swingle, H.S. 1950. Relationships and dynamics of balanced and unbalanced fish populations. Agricultural Experiment Station, Bulletin 274. Auburn, AL: Alabama Polytechnic Institute, $73 \mathrm{pp}$.

Swingle, H.S. \& Smith, E.V. 1942. The management of ponds with stunted fish populations. Transactions of the American Fisheries Society 71: 102-105.
Thorp, J.H. \& Covich, A.P. 1991. Ecology and classification of North American freshwater invertebrates. San Diego, CA: Academic Press, Inc.

Tomcko, C.M. \& Pierce, R.B. 2005. Bluegill recruitment, growth, population size structure, and associated factors in Minnesota lakes. North American Journal of Fisheries Management 25: 171-179.

Witt Jr, A. \& Campbell, R.S. 1959. Refinements of equipment and procedures in electrofishing. Transactions of the American Fisheries Society 88: 33-35.

Wydoski, R.S. \& Wiley, R.W. 1999. Management of undesirable fish species. In: Kohler, C.C. \& Hubert, W.A., eds. Inland fisheries management in North America, 2nd edn. Bethesda, MD: American Fisheries Society, pp. 403-430.

Ylikarjula, J., Heino, M. \& Dieckmann, U. 1999. Ecology and adaptation of stunted growth in fish. Evolutionary Ecology 13: 433-453. 